\title{
EMPIRICAL RESEARCH ON COMPENSATION AWARDS BY THE ISRAEL LABOR COURT IN CASES OF DISMISSALS IN VIOLATION OF DUE PROCESS: THE HEARING AND GOOD FAITH DUTY ${ }^{1}$
}

\begin{abstract}
The Israeli labor law system places a duty on employers to conduct a hearing prior to the dismissal of an employee. It also requires that dismissals should be conducted in good faith. The article presents research undertaken that reveals identifiable tendencies regarding certain factors that influence the court's rulings of compensation rates for the violation of due process. The findings of the research may help parties and their lawyers to predict to some extent the scope of the compensation award to be expected.
\end{abstract}

Słowa kluczowe: niezgodne z prawem zwolnienie, należyte postępowanie, odszkodowanie

Key words: wrongful dismissal, due process, compensation

\section{Introduction}

Under the Israeli labor system, the employer may terminate the labor agreement and dismiss the employee at any time just as the employee may resign at any time. However, the right to dismiss an employee is subject to several restrictions and limitations. Dismissal of employees contrary to the limitations provided by statutes, collective agreements and due process requirements are deemed wrongful dismissals. ${ }^{2}$ Wrongful dismissal contrary to due process requirements, relates to violations of the hearing and the good

1 The article was presented at the III International Conference in Adam Mickiewicz University, Poznań, Poland on $3^{\text {rd }}$ July 2017.

2 R. Ben-Israel, Labor Law, Open University 2002, 2 (Hebrew); N. Feinberg, M. Goldberg, Termination of the Labor Relationship, Sadan Press 2009 (Hebrew); Y. Lubotzky, Termination of Employment, Bar Association Publication, $4^{\text {th }}$ ed., 2013, p. 3-71 (Hebrew), Chapter 5. An example of a limitation on dismissal determined in a statute is the Equal Opportunity Employment Law, Book of Laws 1988, 1240, 38 [Hereinafter: EOEL] restricting discriminatory dismissal. 
faith duties. The issue of violations of due process requirements in dismissals is a major concern in the Israeli labor market due to its wide application by the courts.

Claims of wrongful dismissal are a common lawsuit frequently filed in the Israeli labor courts. Courts in Israel may bestow quiet substantial amounts of compensation for wrongful dismissal claims. Aside from certain broad guidelines set in case law, the judge in a specific case is quiet unrestricted in deciding the rate of compensation. ${ }^{3}$

The article presents findings of the research conducted which examined the manner in which courts value compensation for wrongful dismissal in violation of hearing and good faith duties. The purpose of the research was to create an empirical data base that will assist both the courts and the parties to labor relations in predicting rates of compensation courts award and the factors influencing these rates. It is also hoped that this may lead to more consistency and certainty in compensation rulings for wrongful dismissal contrary to due process requirements.

Section 2 of the article explains the due process requirement in dismissal and the meaning of the hearing and good faith duties. Section 3 of the article presents the way the courts award compensation for violation of each duty. Section 4 contains the methodology of the research. The findings of the research are presented in section 5 and conclusions of the research are displayed in the sixth and final part of the article.

\section{Wrongful dismissal contrary to due process: violation of hearing and good faith duty}

The legal right of the employee to receive a hearing prior to his dismissal is not determined in legislation. ${ }^{4}$ The obligation for a hearing developed in the administrative law and has been recognized in the case law as part of the rules of natural justice. ${ }^{5}$ Michal Horovitz cites the origin of the right to a hearing in the Bible, referring to the story of Abimelech in Genesis, who was saved from death by the hearing, which God granted him. ${ }^{6}$

Haim Beranzon notes there are several legal normative sources of the hearing right, among them is the fundamental constitutional right derived from Basic law: Human Dignity and Liberty. Another cited source has been in Jewish Law and the story of Adam and Eve in Genesis where God granted them a hearing before expulsion from Garden

${ }^{3}$ For wrongful dismissal in violation of a statute there are provisions in the statute that determine limits on compensation rates however they are subject to judicial discretion.

4 T. Frenkel, Compensation without proof of damage, compensation without proof of pecuniary damage and exemplary damages in labor statutes in Israel, Steve Adler Book, Nevo Publishing 2016, p. 497 (Hebrew).

${ }^{5} \mathrm{M}$. Horovitz, A hearing conducted in a superficial manner - the principle of a hearing from an analytical perspective, Law and Business, Radzyner School of Law Pub. 2008-2009, 9, p. 311 (Hebrew) at 328.

${ }^{6}$ Id. at 315 refers to: Genesis chapter 20: Abimelech took Sarah the wife of Abraham to his home but did not approach her. God came to him in his dream and said he was a dead man for taking a man's wife. Abimelech explained she was the sister of Abraham as Abraham introduced her and he did not approach her. God answered he would not kill him if he returned Sarah to Abraham. 
of Eden. The obligation of justice appears not only in the Jewish Bible, but also in the Oral Law set forth in the Talmud. Administrative law and an inherent duty of fairness of the government authority to allow a citizen a hearing before deciding his fate have also been cited as sources for the right to a hearing. ${ }^{7}$

Thus derived from many sources, the hearing is deemed a fundamental right in the Israeli law system and in labor relations. ${ }^{8}$ It is a primary right of the employee to know what allegations are being asserted against him that led to his dismissal and the right to respond to these allegations. ${ }^{9}$ Once this right has been established, the employer has an obligation to present the allegations against the employee fairly, openly and truthfully. ${ }^{10}$ The dismissal hearing is a formal meeting between the employer and the employee where the employer states the reason for dismissal. The employee then has the opportunity to argue against the claims and try to convince the employer not to dismiss him. ${ }^{11}$ There are no formal legal rules for conducting the hearing, but the courts have developed some "rules of thumb". 12

At the hearing, the employer is required to listen to the employee willingly and with an open mind and should be prepared to change his decision. ${ }^{13}$ It is necessary to disclose the real reason for dismissal so that the employee can properly defend himself at the hearing. An announcement of a dismissal, which does not disclose the true reason for dismissal would be deemed a dismissal not in good faith. ${ }^{14}$ The obligation to explain the grounds for dismissal will ensure the exercise of the right to dismiss an employee in an accepted way and in good faith. ${ }^{15}$

${ }^{7} \mathrm{H}$. Berenson, The scope of the hearing duty and the right of inspection in fair administrative hearing procedure in labor relations, in: Essays in Honor of Elika Barak Ussoskin, S. Adler (ed.), Nevo Publisher 2012, p. 327 (Hebrew) at 335: refers to Basic law: Human Dignity and Liberty, 1992, Book of Laws 1992, 1391, 150; Genesis chapter 3; Deuteronomy chapter 1, note 19; Zaks case. And see at 331: the hearing applies to any change to the worse in employment conditions or derogation from the employees' rights. However, the hearing in these situations is out of the scope of the research.

${ }^{8}$ LA 1027/01, Dr. Yossi Guterman v. Emek Yizrael Academic College, 37 PDA 311 Nevo 2003 at 455 paragraph 14.

${ }^{9} \mathrm{Id}$.

${ }^{10} \mathrm{Id}$.

${ }^{11}$ An employee attending a dismissal hearing may be accompanied by a lawyer or a union representative See LC 9466/08, Yoram Shoval v. IBM Global Services Israel, Nevo, 2011. Shoval, at 17 paragraph 72. And see LB (TA) 6741/04, Merav Halperin v. The State of Israel - Office of Security, Nevo, 2008 at 15 paragraph 12.

${ }_{12}$ S. Rabin-Margalioth, Regulating individual employment contracts through good faith duties, Comp. Lab. L. \& Pol'y J. 2010-2011, 32, p. 663, at 678.

${ }^{13} I d$., at 678 .

${ }^{14}$ Merav Halperin case, supra note 11 at 18 paragraph 15.

${ }^{15}$ N. Feinberg, M. Goldberg, Termination of the Labor Relationship, supra note 2 at 49 . And S. RabinMargalioth, Regulating individual employment contracts through good faith duties, supra note 12, notes that the basis for each of these stipulations is the employer's duty of good faith. 
It was the National Labor Court that declared that the due process requirements relate to all types of employment and employers. ${ }^{16}$ The hearing obligation, originally grounded in the public law, expanded from the public to the private employers. ${ }^{17}$ Since 2003, all employers including private sector employers must make termination decisions subject to due process requirements. ${ }^{18}$

Reut Shemer Begas maintains that the hearing obligation required by judicial legislation promotes procedural justice in the workplace and safeguards the dignity of the dismissed employee. ${ }^{19}$ However, she criticizes the extensive application of an administrative hearing process to private sector employers. She suggests that a distinction should be made between public employers and private employers, concerning the application of the procedure of a hearing. Michal Horovitz believes that there is a need to emphasize the economic benefits of exercising the right to a hearing, so it will not become perfunctory, especially in the private sector, simply to "go through the motions". She claims that the right has become devoid of meaning and does not provide protection for employees. ${ }^{20}$

Common to the views presented above is the concern regarding the way that the hearing is being implemented in dismissal situations. ${ }^{21}$ This concern is not detached from the reality of the labor environment. To my own personal knowledge, the hearing process as currently used has been criticized by employers and employees as being a superficial event that does not fulfill its stated goals. It is perhaps not surprising that the Labor Court has also been criticized for the pervasive use of the hearing process.

The source of the good faith duty is in legislation. The Law of Contracts (General Part) in sections 12 and 39, determines a contract should be performed in good faith and negotiations should be conducted in good faith. ${ }^{22}$ These provisions apply also to conduct under the labor contract. Guy Davidov and Ido Eshet claim that the courts in Israel

${ }^{16}$ S. Rabin-Margalioth, Regulating individual employment contracts through good faith duties, supra note 12 at 678 claims the requirement was applied "across the board", and see referral at note 86 to: LA 415/06, Dani Malka v. Supersal Ltd., Nevo, 2007, at 5 paragraph 6.

${ }_{17} \mathrm{H}$. Berenson, The scope of the hearing duty and the right of inspection..., supra note 7 at 331.

18 S. Rabin-Margalioth, Regulating Individual Employment Contracts through Good Faith Duties, supra note 12 at 677 refers to: Yossi Guterman case, supra note 8. And see e.g. Yoram Shoval case, supra note 11 at 18 paragraph 73 .

${ }_{19}$ R. Shemer Begas, Procedural justice and employee dignity in dismissal - reflection on the rule of hearing, Labor Society and Law 2012, 13, p. 175-217 (Hebrew).

${ }^{20} \mathrm{M}$. Horovitz, A hearing conducted in a superficial manner..., supra note 5 at 340 part 5 she finds the hearing is an interest of the employer: it is a tool to receive information about the workplace, a base for trust relationship with the employees, a way to maintain his reputation, a tool to refrain from additional costs and a way for presenting administrative fairness. And see at 313.

${ }^{21}$ Also see $\mathrm{H}$. Berenson, The scope of the hearing duty and the right of inspection..., supra note 7 at 341 , points to the judicialization of the hearing procedure in both the private and the public sector and claims that in the last decade hearing procedures have become more and more formal, due to the involvement of lawyers on both sides.

${ }^{22}$ Law of Contracts (General part), 1973, Book of Laws 1973, 694, 118\$\$12, 39. See targum.babylon- software.com v.10.3.0.14 (translation): good faith is translated to fair and open, honest, good sincere intention. 
developed a strong prohibition to dismiss an employee without good faith, including dismissal without sufficient cause and arbitrary dismissal. ${ }^{23}$ Sharon Rabin- Margalioth claims the good faith duty serves as a regulatory mechanism to design employment process rights. An example of regulating due process rights is the hearing process. ${ }^{24}$

\section{Compensation awards in cases of dismissals in violation of the hearing or good faith duty}

There is no one mandated method in which the labor court must determine compensation amounts for wrongful dismissal in violation of the hearing or good faith duty. Compensation awarded by the court for the absence of a hearing or improper hearing procedure prior to dismissal is usually calculated according to multiples of one to twelve monthly salaries in the court's discretion. ${ }^{25}$ Granting compensation which is above an annual salary is rare. ${ }^{26}$ However, in some cases, compensation has been determined by the court as an all-inclusive amount.

Reut Shemer Begas claims that the right to a remedy due to an improper dismissal procedure is an independent source of remedy and a separate category of tort. ${ }^{27}$ Furthermore, she maintains that an award of compensation on the basis of the number of salaries sends the wrong message to employees and employers that the dignity of employees is derived from their salary. She claims a more worthy judicial policy should be to disconnect the rate of compensation from the salary and to decide each case on its merit. ${ }^{28}$

${ }^{23}$ G. Davidov, I. Eshet, Job security: toward balanced intermediate solutions, Mishpatim 2012, 43, p. 143-181 (Hebrew) at 160.

${ }^{24}$ S. Rabin-Margalioth, Regulating individual employment contracts through good faith duties, supra note 12 at 674, 677-680. And see: Y. Lubotzky, Termination of Employment, supra note 2 at 36-44, states dismissal should be in good faith. For example, dismissal due to political reasons is dismissal without good faith with reference to HCJ 4284/08, Kelpner $v$. Mail Company of Israel Ltd., Nevo, 2010.

${ }^{25}$ The court determined that while the absence of a hearing is a flaw in the dismissal, it was not an absolute flaw and does not necessarily lead to cancelling the dismissal or to a compensation award to the employee. The type and extent of the remedy depends on the circumstances of the case. See LA (National) 701/07, Israel Electrical Company Ltd. v. Shlomy Turgeman, Nevo, March 2009 at 11 paragraph 17. And see LA (National) 21781-10-10, Lulu Rashad $v$. Regional Committee for planning and construction Alonim, Nevo, July 2013, at 31 paragraph 65.

${ }^{26}$ Merav Halperin case, supra note 11 at 17-18 paragraph 16: the court determined that the top limit rate of compensation for wrongful dismissal is one year's salary. Only in exceptional cases the amount will exceed one year salaries. And see: LA (National) 17365-11-11, Jaclyn Swisa v. Yahud Municipality, Nevo, 2014 at 57 paragraph 73. And see LA (National) 456/06, Tel Aviv University $v$. Rebeca Elisha, Nevo, 2008 and see, HCJ 4485/, Rebeca Elisha $v$. Tel Aviv University, Nevo, 2009 at 17 paragraph 18. The dismissal circumstances were severe and the court granted particularly high compensation of 24 salaries. And see Y. Lubotzky, Termination of Employment, supra note 2 chapter 5 at 67 note 328.

27 R. Shemer Begas, Procedural justice and employee dignity in dismissal..., supra note 19.

${ }^{28}$ Id., at 216-217. 
In the Israeli labor system, the good faith duty and the hearing duty are intertwined. As part of the good faith duty, the employer must present the employee with the real reason for his dismissal in order for him to explain and rebut the allegations against him in the hearing. ${ }^{29}$ However, there are other situations of wrongful dismissal due to a violation of the good faith duty. For the purposes of this paper, an attempt has been made to separate the hearing and good faith duties in order to conduct a precise and accurate analysis. Yet, the division between hearing duty and good faith duty is not clear cut. At times, the good faith duty is applied by the court to wrongful dismissal that is not connected to the hearing duty. ${ }^{30}$ At other times, it is applied as the principle reason for dismissal done in violation of the hearing duty. ${ }^{31}$ Thus, a violation of the good faith duty may be due to the presentation of an untrue reason for dismissal ${ }^{32}$, or a violation of the good faith duty as a result of the general behavior of the defendant or the reason leading to the dismissal ${ }^{33}$. A violation of good faith duty may also be by the conduct of the labor contract without good faith in dismissal. ${ }^{34}$ However, once the violation has been found, the calculation of compensation usually is according to salaries.

\section{Research methodology and research questions}

The method chosen for the research was empirical legal research. The use of empirical research methodology has accelerated in the legal academia in recent years, but is relatively new in Israel. ${ }^{35}$ Theodore Eisenberg claims empirical legal research obtains

${ }^{29}$ Merav Halperin case, supra note 11 at 18 paragraph 15. And see N. Feinberg, M. Goldberg, Termination of the Labor Relationship, supra note 2 at 49.

30 For example, In LCT 3404-10, Ela Greenberg Nachshon v. Proporzia, Nevo, June 2013. In that case, the employee was dismissed one day before the requirements of the Woman Employment Law would have applied (6 months after employment). See Woman Employment Law, 1954, Book of Laws 1954160 , 154 [Hereinafter: WEL] $\$ 9$.

31 For example, in LA 44309-05-11, Shiri Lahav $v$. State of Israel-Foreign Affairs Office, Nevo, January 2013, the court found a "heavy cloud of absence of good faith and illegality" in the dismissal without hearing of a civil servant in a position of trust (involving an office manager of the deputy minister of the Foreign Affairs Office). The absence of the hearing was itself perceived by the court as a breach of the good faith duty.

32 See the Merav Halperin case, supra note 11.

33 See for example DM 54842-03-11, Ronny Mey-Tal v. Optica Hador Hashlishy Ltd., Nevo 2012. Appeal: ruling confirmed 2013: BRA (National) 41339-10-12. An employee was dismissed after 10 days of employment. Mey-Tal had been hired for the job without the qualifications needed for the job. This was known and so stated by the employer. The employer, however, declared that Mey-Tal would be acquiring the qualifications during the first three month of employment. Nonetheless, the employer dismissed her after 10 days before she could acquire training on the basis that she was not qualified for the position. The court determined the employer had acted without good faith in the dismissal.

34 See Ela Greenberg Nachshon case, supra note 30.

35 L. Berlin, M. Katz Maayan, A. Faust (eds.), Empirical legal studies: introduction, Tel Aviv U. L. Rev. 2011, 34, p. 293 (Hebrew), at 293, 294, 296. 
and analyzes a collection of facts from a computerized legal database and the modest aim of such research is to collect data about the way the legal system operates. ${ }^{36}$

The database of cases for the research includes court rulings gathered from the online computerized electronic legal database published by "Nevo Publishing Ltd." ${ }^{37}$

The research period includes court rulings of compensation for wrongful dismissal from $1 / 1 / 2013$ to $31 / 12 / 2014$. The research period chosen was the most recent two years available at the time the research was conducted. The recent tendency prevailing in Israeli courts is the focus of interest of the research. The research does not look for changes occurring during the years examined.

The factors, circumstances and considerations influencing court rulings and prevailing tendencies in court compensation rulings were identified and revealed, based on the reasoning or rational the courts give for awarding specific values of compensation in specific cases. The initial assumption of the research was that there are six factors that influence court determinations of compensation: salary level, reason for dismissal, period of employment, occupation, the gender and the age of the plaintiff. The cases collected were reviewed and analyzed according to the assumed influencing factors. ${ }^{38}$ Cases gathered relating to wrongful dismissal with violation of due process amount to 87.70 cases were identified involving wrongful dismissal without hearing. 17 cases were identified involving wrongful dismissal in violation of the good faith duty. ${ }^{39}$ The study reviewed rulings of the Regional Labor Court and National Labor Court. ${ }^{40}$

${ }^{36}$ T. Eisenberg, The origins, nature, and promise of empirical legal studies, Tel Aviv U. L. Rev. 2011, 34, p. 303 (Hebrew) at 310-311. Eisenberg states that the legal empirical approach has developed rapidly and is growing. It is a way to collect systematical substantial data without connection to the normative implications. He finds legal empirical research serves as a useful bridge between legal academia and legal practice.

${ }^{37}$ Nevo is one of the largest and most used computerized legal publishers in Israel. Nevo database contains court rulings of Israeli courts, legislation and legal literature. As part of the identification of the relevant cases, database searches were conducted using the following keywords: "labor"; "dismissal"; "hearing duty"; and "absence of good faith".

${ }^{38}$ The reasoning of the court for awarding the rate of compensation was noted in every case where provided by the court. The data regarding compensation rates and influencing factors was analyzed and summarizes into tables and the explanations provided by the courts were applied to the data results.

${ }^{39}$ Some of the good faith violation cases also include violations of the hearing duty. Some of the cases were listed as those involving claims pursuant to the statute violations. The cases obtained by the research amounted to 94 cases including cases relating to statute violations: WEL supra note 30 and EOEL supra note 2. As such, there is an overlap between the cases of hearing, good faith, and those relating to statute violations. Nevertheless, every case was recorded once. See about research of wrongful dismissal in violation of a statute: Y. Ilany, Compensation award for wrongful dismissal of pregnant women in Israel, Studia Edukacyjne, University Adam Mickiewicz, Poznań 2016, 41, p. 359.

${ }^{40}$ The lower instance is the Regional Labor Court and the higher instance is the National Labor Court. See: Labor Court Law, 1969, Book of Laws 1969, 553, $70 \$ 2$. For cases that were commenced in the Regional Labor Court and appealed to the National Labor Court, only the decision of the National Labor Court was included in the study since this was the final ruling of the particular case. However, some cases have an appeal pending in the National Labor Court that still has not been decided upon. 


\section{Findings of research}

First, certain limitations in the research are noted. As presented, often awards of hearing and good faith duty violations are intertwined and in some cases the court referred to them together as one. Another limitation found is that compensation awarded for wrongful dismissal in violation of the hearing and good faith duties may be part of a larger sum awarded by the court which may influence the court in determining the amount to be allocated for the specific violations of the hearing and good faith duties. An additional limitation derived from cases where the court awarded a comprehensive amount for several claimed wrongs. ${ }^{41}$ As a result, the number of salaries awarded was not isolated only for the violations of the hearing or good faith duty and was combined with other violations awards. The cases examined had the further limitation that in some decisions the underlying salary level was not mentioned by the court. Thus, an important element for comparison between rulings was missing. A final limitation on the research of wrongful dismissals for violations of the good faith duty was the limited base of data (17 cases).

Second, the findings regarding factors influencing compensation rates are set out:

- Multiples of salary awarded - for dismissal in violation of the hearing duty the average number of salaries of compensation awarded was 3.5 salaries. ${ }^{42}$ An analysis of the number of salaries awarded shows that the tendency of the court was mostly to award below the average compensation for wrongful dismissal in violation of hearing. ${ }^{43}$ For dismissal in violation of the good faith duty the average number of salaries awarded for wrongful dismissal was 7 salaries. ${ }^{44}$ The distribution of cases between above and below average compensation award did not reveal a significant tendency of the court rulings. ${ }^{45}$

- Salary level - for both wrongful dismissal in violation of the hearing and the good faith duties, a higher salary level will usually yield a higher amount of compensation awarded. Awards of similar multiples of monthly salaries produced very different

${ }^{41}$ For example compensation for a violation of the hearing duty that was combined with compensation for mental anguish. See LD 47439-08-11, Meir Sagi v. Apcon Holdings Ltd., Nevo, December 2013.

${ }^{42}$ In 13 cases out of 70, the salary of the plaintiff was unknown. Therefore, the base for comparison between the cases was 57 cases. Calculation of the average was by adding 57 salary number awarded and dividing the total to 57 cases to produce an average. The lowest award of compensation by the court for wrongful dismissal in violation of the hearing duty was half a salary. The highest compensation award by the court was 18 salaries.

${ }^{43}$ Compensation below the 3.5 average was awarded in 39 cases out of 57 cases. Compensation above the average was awarded in 18 of the 57 cases.

${ }^{44}$ Information about the level of the salary of the plaintiff was present in 11 cases out of 17 cases. The lowest multiple of monthly of salaries awarded was 1.7 salaries. The highest number of salaries awarded was 18 salaries.

${ }^{45}$ Above the average salaries were awarded in 5 of the 11 cases, while below average salaries were awarded in 6 cases. 
totals for compensation due to variations in the level of the base annual salary. ${ }^{46}$ Awards of a large multiple of salaries when combined with a relatively high base salary resulted in relatively high compensation. ${ }^{47}$ In some cases, the court declares explicitly that the level of salary was taken into account in determining the total compensation. ${ }^{48}$ It appears therefore that the court when determining the number of salaries was aware of the level of salary and it influenced the total amount of compensation.

- Reason for dismissal - for wrongful dismissal in violation of the hearing duty, in the majority of cases with a justified reason for dismissal, the plaintiff employees were awarded compensation multiples below the average. ${ }^{49}$ The court declared that when dismissal was due to legitimate and relevant reasons, the compensation awarded for flaws in dismissal procedure should be low. ${ }^{50}$ The court stated that not every violation of the duty to conduct a hearing will result in an award of compensation and the compensation will be determined by the circumstances and the severity of the violation. ${ }^{51}$ However, the same tendency of the court towards low multiples of compensation was apparent in cases of hearing violations for unjustified reasons for dismissal. ${ }^{52}$ Cases of justified or unjustified reasons for dismissal mostly were awarded below average salary multiples. This suggests the reason of dismissal was not overall an influencing factor on the compensation determination. For wrongful dismissal in violation of good faith duty, in cases with justified reason for dismissal the tendency of the court appears inconclusive and it is not possible to draw conclusions on the basis of the small database. ${ }^{53}$ In cases with unjustified dismissals the awards of compensation diverged. ${ }^{54}$ Nevertheless, an unjustified reason for dismissal in most cases did not lead to higher compensation award for violation of the good faith duty. On the other hand, when the reason for dismissal was justified, a violation of the good faith duty can result in exceptionally high awards. ${ }^{55}$ Therefore, the reason for dismissal

46 For example compare LD (NZ) 14831-03-11, Ina Marosiak v. Plakstroniks (Israel) Ltd., Nevo, April 2013 and LC 6664-09, Shiri Rubin v. Mz point I.T. Ltd, Nevo, February 2013.

47 For example LD 9895-09, Yitzhak Tomer $v$. The Management College, Nevo, October 2013.

48 See example LD 57883-01-13, Vaks Eduard v. Galey Hazuk Ltd., Nevo, December 2014

49 In 32 cases out of 70, the reason for dismissal was justified by the court. 27 of these cases included information about the salary level. Below average compensation were awarded in 20 out of 27 cases.

50 For example LD 9122-10-12, Noam Zandar v. Orgad Ltd., Nevo, May 2014 at 17 paragraph 39.

51 See LD 7633-03-12, Gil Moshe Shpilfogel v. Medical Care Towers, Nevo, August 2014.

52 In 38 cases the reason for dismissal was unjustified. In 30 cases the level of salary was presented. In 20 of the 30 cases, the court awarded compensation below the average.

53 In four of the seventeen cases the reason for dismissal was justified. In two of these cases, the court awarded above average compensation. In one case below average compensation was awarded and in one case the salary level was unknown.

5413 of 17 cases of violation of the good faith duty involved unjustified dismissals. The level of the employee's salary was disclosed in 8 cases. In three of the eight cases, above average compensation was awarded and in five cases the award was below average.

55 See LD 53875-10-10, Ezra Saadia v. Givatayim Municipality, Nevo, September 2014. 
seems not to be a major factor influencing compensation for violation of the good faith duty.

- Entity of the employer - for both wrongful dismissal in violation of the hearing and good faith duties the findings show that a factor influencing compensation award by the court was the entity of the employer and specifically whether the employer was a public or hybrid public/private entity. ${ }^{56}$ The court determined that stricter obligations apply to the state regarding their employees and the dismissal of employees. ${ }^{57}$ For the hearing violation, it would seem that the severity of flaws in the dismissal procedure were a factor influencing compensation viewed in combination with the entity of the employer. When the flaws in the dismissal procedure were significant, the fact that the employer was a public entity did influence the compensation. ${ }^{58}$ However, when the flaws in the hearing were not significant, the entity of the employer was not an influencing factor. ${ }^{59}$ In contrast, for wrongful dismissal in violation of the good faith duty in all the identified cases involving a public or hybrid public/private entity, compensation was above average or in the amount claimed by the plaintiff. Thus, the employers' entity status was a significant influencing factor on compensation in cases of wrongful dismissal without good faith.

- Period of employment and age - both factors were found as influencing compensation awards for both wrongful dismissal in violation of the hearing and good faith duties. ${ }^{60}$ Generally, a short period of employment led to below average compensation. ${ }^{61}$ Moreover, in several cases, the court determined explicitly that short time employed plaintiffs should be awarded a low compensation for violation of the hearing duty. ${ }^{62}$ Concerning cases involving long periods of employment, most employees were awarded above the average compensation by the court. ${ }^{63}$

56 See Yitzhak Tomer case, supra note 47, at 8 paragraph 18, 21: the court determined that the rules of public and administrative law apply to the hybrid public/private entity similar to their application to a public employer. This meant that heightened duties of fairness and good faith applied to the hybrid public/private entity and that the dismissal procedure will be examined under administrative laws.

57 Shiri Lahav case, supra note 31, an employee of the State of Israel (Foreign Affairs Office).

58 See Ezra Saadia case, supra note 55.

59 See LD 5776-02-13, Osnat Cohen v. Student Association Emek Yizrael College, Nevo, August 2014.

60 For purposes of the research, a period of employment of less than five years was deemed a short term period of employment, while period of five years or more were considered long term employment.

61 This finding was significant for the hearing violation, appearing in 32 of the 38 cases involving short time employment. For the good faith violation in most of cases involving short time employment, appearing in 5 of 6 cases.

62 See example Gil Moshe Shpilfogel case, supra note 51.

63 For the hearing violation in 11 out of 19 cases the compensation awarded by the court was above average. In the remaining 8 cases the compensation awarded was below average. The correlation was less significant than the correlation in the findings demonstrated for short time employment plaintiffs. For the good faith violation in 4 of 5 cases of long time employment plaintiffs were awarded above average compensation. 
In majority of cases the age of the plaintiff was unknown. ${ }^{64}$ Although a small sample, the younger age group was mostly awarded below average compensation. ${ }^{65}$ For the older age group there was a tendency of compensation awards above the average. ${ }^{66}$ The link between the factors of age and period of employment in court awards was demonstrated in the findings. The employees in the older age group who had served in long time employment generally were awarded above average compensation. ${ }^{67}$ Although a small sample size, the employees of the younger age group who had a short time employment received a below average compensation in the cases where these features had been identified. ${ }^{68}$

- Gender - for wrongful dismissal in violation of the hearing duty it seems there was no tendency of the court concerning gender as a factor influencing compensation. ${ }^{69}$ However, for the good faith violation, in all cases involving a female plaintiff the award was below the average compensation. ${ }^{70}$ In none of the cases of a female plaintiff was the plaintiff awarded above the average of salaries. In contrast, most of the male plaintiffs were awarded above the average of salaries. ${ }^{71}$ It would seem that the court took gender into consideration when awarding compensation for dismissal without good faith and this factor influenced males receiving higher compensation than females. ${ }^{72}$

- Occupation - for both hearing and good faith violations it was found that the employees that received above the average compensation and employees that

${ }^{64}$ The age factor was categorized for the research purpose into two groups. The first age group was defined from 20 to 50 years old and the second group was defined from 51 to the retirement age of 67 years old. For the hearing violation, in fifteen cases, the age and the period of employment were identified by the court. In the remaining 55 cases, the age of the employee was unknown.

${ }^{65}$ For the hearing violation, four cases involved employees in the younger age group.

${ }^{66}$ For the hearing violation, 11 cases involved older age employees. Seven of the cases were awarded above average compensation. Four cases were awarded below the average compensation.

${ }^{67}$ For the hearing violation, in 5 cases out of 7 . For the good faith violation 4 cases out of 5 .

${ }^{68}$ For the hearing violation in 3 cases out of 4 . For the good faith violation in one case out of one therefore it is doubtful if a conclusion can be reached.

${ }^{69}$ The division of the 70 cases researched between female and male plaintiffs was 40 cases involving female employees and 30 cases involving male employees. The salary level was disclosed in 31 cases for females and 26 cases for males. Ten of the 31 female plaintiffs were awarded above the average compensation, while 21 female plaintiffs were awarded below the average. Eight of the 26 male plaintiffs were awarded above the average compensation, while 18 male plaintiffs were awarded below the average compensation.

${ }^{70}$ Among the 17 cases, nine involved female plaintiffs and in eight the plaintiff was male. There were only four cases of female plaintiffs were the salary of the plaintiff was known.

${ }^{71}$ Male employee's salary level was known in 7 cases out of 8 . In 5 out of 8 cases the award was above the average. Below the average compensation was awarded in 2 cases.

${ }^{72}$ However, this conclusion is limited since in 5 of the 9 cases of female plaintiffs, the salary was unknown, leaving a base of only 4 cases for analysis of female compensation awards. This may suggest that the conclusion is not accurate. 
received below the average compensation were from a variety of occupations. ${ }^{73}$ For cases involving the same occupation, some were awarded compensation above the average, while others received awards that were below the average. ${ }^{74}$ Occupation itself did not seem to affect the compensation award and was not an influencing factor for the court in determining compensation.

\section{Summary and conclusions}

The extensive number of cases (70) identified for the period researched involving wrongful dismissal with violations of the hearing duty shows how frequent such claims were submitted to the court. In contrast, for the same period, far fewer claims (17) were submitted for violations of the good faith duty. It is suggested here that the good faith claim will probably become more common in the future. One of the reasons it is expected that the number of such claims will increase is the higher compensation awarded by the court for wrongful dismissal involving violations of the good faith duty. The average number of salaries awarded for violations of the hearing duty were lower (average of 3.5), than the number of salaries awarded for violations of the good faith duty (average of 7). This is an important indication of a tendency of the court to treat wrongful dismissals in violation of good faith more severely than violations of the hearing duty and awarding higher compensation. Furthermore, it seems the court is expanding the application of the good faith duty to more situations of wrongful dismissal. ${ }^{75}$ It is suggested that the list of circumstances and situations where the court will find wrongful dismissal based on a lack of good faith is open and expanding.

The lower average number of salaries awarded for violation of the hearing duty is an important indication of the courts tendency towards limiting compensation for this violation. Although the range of awards for the hearing violation has been between 1 and 12 salaries, the recent tendency of the court has been to award a relatively low number of salaries for this violation. This empirical finding suggests that the court may be hearing the debate going on in Israel about the pervasive implementation of the hearing duty in event of termination of labor relations. In my opinion, the criticism expressed by scholars, as well as, the parties to labor relations concerning the broad application of the hearing duty to a wide range of situations and its expansion to all employers and all employees has led to deterioration of awards for hearing violations. Scholars contend that the hearing duty has become an artificial process performed by employers without

${ }^{73}$ For example a human resources manager is a supposedly high rank occupation, while a part time worker in a kindergarten is supposedly a low rank occupation and both received below average compensation.

${ }^{74}$ For example salespersons were awarded compensation both above and below the average.

75 See part 3 of this article and for example note 30,31 . 
a genuine sincere intention to hear the employee's claim. ${ }^{76}$ The low average number of salaries awarded for hearing violations suggests that the court has been influenced by this criticism. Although the duty is applied widely by the courts, the penalty paid by employers for violations were usually not high.

The level of salary was found empirically as a factor influencing the amount of compensation. In my opinion, the fact that the court considers the salary level of the plaintiff as a factor in awarding compensation suggests that the court calculates total amount that will be reached when a multiple of salaries is applied to the level of the monthly salary. Thus, when the salary is relatively high or relatively low the court will adjust the number of salaries awarded to reach a predetermined end sum that the court finds appropriate in the circumstances of the specific case.

The conclusion of the research that level of salary of the plaintiff is an influencing factor on compensation amounts awarded by the court, empirically supports the statements of Reut Shemer Begas and of Judge Ilan Itah. ${ }^{77}$ They express concern regarding the connection between the level of salary and the amount of compensation awarded by the court. According to Shemer Begas and Itah, the court conveys the message to parties that the sorrow and pain of a plaintiff earning a higher salary is worth higher compensation than that of a plaintiff earning a lower salary. The findings confirm that a high salaried employee will generally be awarded higher total compensation for wrongful dismissal than a low salaried employee.

For cases involving a wrongful dismissal in violation of the hearing and good faith duties, it may seem that the reason for the dismissal was not a major factor influencing the determination of compensation. However, when the reason for the dismissal was justified, in certain cases, the court treated violations of the hearing with less severity and found the hearing process less significant. In my opinion, this deterioration in the hearing requirement and the dilution of compensation awards for hearing violations are acceptable when the reason of dismissal is justified. However, for cases where the cause of dismissal was unjustified, they are problematic. In these cases, a hearing conducted truthfully and genuinely can lead the employer to cancel the dismissal. The tendency of the court to downgrade the importance in conducting such hearings and reducing awards for violations undermines the objectives of the hearing duty. Nevertheless, for violation of the hearing duty an unjustified reason for dismissal influenced the total compensation amount and not the compensation amount for the hearing violation. ${ }^{78}$ Additionally, in certain cases where the manner of dismissal was flawed severely above

${ }^{76}$ See M. Horovitz, A hearing conducted in a superficial manner..., supra note 5 and see R. Shemer Begas, Procedural justice and employee dignity in dismissal..., supra note 19.

77 See: Judge Ilan Itah in LA (National) 43380-06-11, Plony $v$. Almonit, Nevo, 2014. And see R. Shemer Begas, Procedural justice and employee dignity in dismissal..., supra note 19 and in part 3 of this article notes $27,28$.

${ }^{78}$ For example, a case of age discrimination: case Meir Sagi, supra note 41, awarded below average compensation for a hearing violation nonetheless, the total compensation awarded was 11.6 salaries. 
the average compensation was awarded for both justified and unjustified dismissals. ${ }^{79}$ So in these cases, the manner of dismissal led to the high compensation regardless of the reason for dismissal.

The findings also show that the period of employment and age of the employee were influencing factors for wrongful dismissal in violation of both the hearing and good faith duties. A short time of employment and a younger age employee will generally be awarded lower compensation. In cases where there had been a long period employment and the age of the employee was older, generally the award will be higher compensation. ${ }^{80}$

Occupation was not found to be an influencing factor in cases of wrongful dismissal in violation of either the hearing duty or good faith duty. The tendency of the court was to consider the violation and its severity equally to all ranks of workers. High level employees did not receive better treatment from the court than low ranking workers or vice versa. In my opinion, this is a particularly important finding of this research. It shows that the court is influenced by factors relevant to the circumstances of the case without being affected by the rank, prestige or social connections of the plaintiff wrongfully dismissed. In this, the court sends a message that employees at all levels of employment will be treated equally.

Gender was not found to be an influencing factor on compensation awards for wrongful dismissal in violation of the hearing duty. However, in cases involving wrongful dismissal in violation of good faith, the findings show a significant difference of compensation amounts in favor of males. This is an interesting finding and suggests that the court perceived the harm of a violation of the good faith duty to be more severe for males than for females. In my opinion, this is contrary to the principle of equality that should be guiding the court.

Yet, a close examination of the cases in which males were awarded a higher compensation does show a correlation to a long period employment and an older age. A possible explanation is that in the Israeli labor market male employees usually feature these characteristics of long periods of employment and belonging to older age group. It may be that gender in itself was not the influencing factor on compensation, but rather the plaintiff specific age and period of employment of the employee that influenced the decision. ${ }^{81}$

Another tendency of the court was in its consideration of a collection of factors leading to a higher compensation, rather than an isolated factor. In addition, the entity form of the employer was a factor influencing awards made by the court for violations

${ }^{79}$ In seven of the 27 hearing violation cases with justified reason for dismissal. For cases of unjustified dismissals in 10 of 30 cases.

${ }^{80}$ Lower or higher compensation amount is compared to the average compensation defined in the research findings.

${ }^{81}$ See and compare to LD 4701-05-16, Madi Levy v. IBM, Nevo, August 2016, paragraph 38, 51. A recent case of wrongful dismissal of a female employee was awarded high compensation (14.5 salaries) for violation of the hearing duty, absence of good faith and discrimination. The plaintiff, 60 years old, employed for 35 years, was discriminated on base of age and her right for due process was violated. 
of the hearing duty and more so for violation of the good faith duty. It was clear that when confronted with good faith duty, the court holds public and hybrid public/ private employers to a higher standard of good faith conduct towards their employees and awards higher compensation amounts.

The research undertaken in this paper reveals that there are indeed identifiable tendencies regarding certain factors that would indicate the parameters of an award for compensation in cases of wrongful dismissal. The research reveals tendencies regarding certain factors that may help parties and their lawyers to predict to some extent the scope of the compensation award to be expected. However, there is no unity in court determinations of compensation. Some judges follow a pattern or a guideline for determining compensation, ${ }^{82}$ while others find reasoning to support their decision that fit the specific case. ${ }^{83}$ Nevertheless, the empirical database developed by the research would aid parties and their lawyers to predict an expected range of a compensation award in a situation of wrongful dismissal. It also may serve as a guideline and basis for courts in making rulings of compensation for wrongful dismissal. However, the amount a specific judge will award in an individual case is influenced by the individual view of the judge and is ultimately not easily predicted. Thus, in my opinion, the amount of compensation finally awarded by the courts depends on the judge's approach and perception of the case and the amount that she or he considers appropriate. As such, although factors will indicate direction and an expected scope for an award, the basis used by a judge in exercising his or her discretion is not easily predictable and may be to a certain extent arbitrary. The notion of somewhat arbitrary determinations of compensation amounts by the courts was in accordance with the opinions of scholars regarding non pecuniary damages ${ }^{84}$

\section{References}

\section{Legislation}

Basic law: Human Dignity and Liberty, 1992, Book of Laws 1992, 1391, 150.

Equal Opportunity Employment Law, 1988, Book of Laws 1988, 1240, 38.

Labor Court Law, 1969, Book of Laws 1969, 553, 70.

${ }^{82}$ For example determination of compensation by multiple of number of years of employment and salary. LD 46048-01-11, Bat Sheba Cohen v. Ramat David Special Education, Nevo, March 2013.

${ }^{83}$ For example the court states the determination of compensation is "due to circumstances" in case Meir Sagi, supra note 41.

${ }^{84}$ See: Y. Bitton, Dignity aches: compensating constitutional harms, Mishpat Umimshal (Haifa University LR) 2005, 9, 2 p. 137 (Hebrew), and see G. Shalev, Y. Adar, The Law of Contract - Remedies for Breach, Towards Codification of Israeli Civil Law, Din Publishers Ltd. 2009 (Hebrew) at 300. And see D.B. Dobbs, Law of Remedies, Damages-Equity-restitution. Abridgement, $2^{\text {nd }}$ ed., West Publishing 1993 at 211 claims it is not possible to quantify and prove in evidence non-pecuniary harm. And see: D. Friedman, N. Cohen, Contracts, Vol. 4, Aviram Publishing Ltd. 2011 (Hebrew), at 675 they note that non-pecuniary damages are difficult to assess, because they are not economical. 
Law of Contracts (General Part), 1973, Book of Laws 1973, 694, 118

Woman Employment Law, 1954, Book of Laws 1954 160, 154.

\section{Case Law}

LA 1027/01, Dr. Yossi Guterman v. Emek Yizrael Academic College, 37 PDA 311, Nevo, 2003. LA 415/06, Dani Malka $v$. Supersal Ltd., Nevo, 2007.

LB (TA) 6741/04, Merav Halperin $v$. The State of Israel - Office of Security, Nevo, 2008.

LA (National) 456/06, Tel Aviv University v. Rebeca Elisha, Nevo, 2008.

HCJ 4485/08, Rebeca Elisha v. Tel Aviv University, Nevo, 2009.

LA (National) 701/07, Israel Electrical Company Ltd. v. Shlomy Turgeman, Nevo, March 2009. HCJ 4284/08, Kelpner v. Mail Company of Israel Ltd., Nevo, 2010.

LC 9466/08, Yoram Shoval v. IBM Global Services Israel, Nevo, 2011.

DM 54842-03-11, Ronny Mey-Tal v. Optica Hador Hashlishy Ltd., Nevo 2012. And BRA (National) 41339-10-12, 2013.

LA (National) 21781-10-10 Lulu Rashad v. Regional Committee for planning and construction - Alonim, Nevo, July 2013.

LA (National) 43380-06-11, Plony v. Almonit, Nevo, 2014.

LA (National) 17365-11-11, Jaclyn Swisa v. Yahud Municipality, Nevo 2014.

LD 4701-05-16, Madi Levy v. IBM, Nevo, August 2016.

\section{Cases of the research}

LA 44309-05-11, Shiri Lahav v. State of Israel-Foreign Affairs Office, Nevo, January 2013.

LC 6664-09, Shiri Rubin v. Mz point I.T. Ltd, Nevo, February 2013.

LD 46048-01-11, Bat Sheba Cohen $v$. Ramat David Special Education, Nevo, March 2013.

LD (NZ) 14831-03-11, Ina Marosiak v. Plakstroniks (Israel) Ltd. Nevo, April 2013.

LCT 3404-10, Ela Greenberg Nachshon v. Proporzia, Nevo, June 2013.

LD 9895-09, Yitzhak Tomer $v$. The Management College, Nevo, October 2013.

LD 47439-08-11, Meir Sagi v. Apcon Holdings Ltd. Nevo, December 2013.

LD 9122-10-12, Noam Zandar v. Orgad Ltd., Nevo, May 2014.

LD 5776-02-13, Osnat Cohen v. Student Association Emek Yizrael College, Nevo, August 2014.

LD 7633-03-12, Gil Moshe Shpilfogel v. Medical Care Towers, Nevo, August 2014.

LD 53875-10-10, Ezra Saadia v. Givatayim Municipality, Nevo, September 2014.

LD 57883-01-13, Vaks Eduard v. Galey Hazuk Ltd., Nevo, December 2014.

\section{Literature}

Ben-Israel R., Labor Law, Open University 2002, 2 (Hebrew).

Berenson $\mathrm{H}$., The scope of the hearing duty and the right of inspection in fair administrative hearing procedure in labor relations, in: Essays in Honor of Elika Barak Ussoskin, S. Adler (ed.), Nevo Publisher 2012 (Hebrew).

Berlin L., Katz M., Faust A. (eds.), Empirical legal studies: introduction, Tel Aviv U. L. Rev. 2011, 34 (Hebrew). 
Bitton Y., Dignity aches: compensating constitutional harms, Mishpat Umimshal (Haifa University LR) 2005, 9, 2 (Hebrew).

Dobbs D.B., Law of Remedies, Damages-Equity-restitution. Abridgement, $2^{\text {nd }}$ ed., West Publishing 1993.

Davidov G., Eshet I., Job security: toward balanced intermediate solutions, Mishpatim 2012, 43 (Hebrew).

Eisenberg T., The origins, nature, and promise of empirical legal studies, Tel Aviv U. L. Rev. 2011, 34 (Hebrew).

Feinberg N., Goldberg M., Termination of the Labor Relationship, Sadan Press 2009 (Hebrew). Frenkel T., Compensation without proof of damage, compensation without proof of pecuniary damage and exemplary damages in labor statutes in Israel, Steve Adler Book, Nevo Publishing 2016 (Hebrew).

Friedman D., Cohen N., Contracts, Vol. 4, Aviram Publishing Ltd. 2011 (Hebrew).

Horovitz M., A hearing conducted in a superficial manner -the principle of a hearing from an analytical perspective, Law and Business, Radzyner School of Law Pub. 2008-2009, 9 (Hebrew). http://www.nevo.co.il

Ilany Y., Compensation award for wrongful dismissal of pregnant women in Israel, Studia Edukacyjne, University Adam Mickiewicz, Poznań 2016, 41.

Lubotzky Y., Termination of Employment, Bar Association Publication, $4^{\text {th }}$ ed., 2013 (Hebrew).

Rabin-Margalioth S., Regulating individual employment contracts through good faith duties, Comp. Lab. L. \& Pol'y J. 2010-2011, 32.

Shalev G., Adar Y., The Law of Contract - Remedies for Breach, Towards Codification of Israeli Civil Law, Din Publishers Ltd. 2009 (Hebrew).

Shemer Begas R., Procedural justice and employee dignity in dismissal - reflection on the rule of hearing, Labor Society and Law 2012, 13 (Hebrew).

targum.babylon- software.com v.10.3.0.14 (translation) 